\title{
Impact of Laser on Microorganisms in the Digestate
}

\author{
Rasma Tretjakova, Lyubomir Lazov, Andris Martinovs, Samanta Marija Misiņa \\ Rezekne Academy of Technologies, Faculty of Engineering, \\ Research Center Chemical, Biology and Biotechnology \\ Address: Atbrivosanas aleja 115, Rezekne, LV-4601, Latvia
}

\begin{abstract}
At the biogas plant total of 40 digestate samples have been collected and investigated. The microbiological composition of digestate has been analysed before and after laser processing with wavelength $\lambda 445$ nm with power 2 - 4 W. Salmonella spp. has not been stated in any of the samples, Escherichia coli and Enterococcus spp. amount does not correspond Eiropean Union regulation R142/2011 requirements in any of the investigated samples; Staphylococcus aureus has been stated in 24 samples out of 40 . By decreasing laser scanning speed and increasing power, the total number of microorganism colonies in digestate has decreased.
\end{abstract}

Keywords: laser, digestate, bacteria.

\section{INTRODUCTION}

The on-farm production of renewable energy from animal manures has rapidly expanded in central and northern Europe, with thousands of anaerobic reactors [1]. Nowadays there are several biogas plants in agricultural industry in Latvia. Anaerobic digestion converts waste material into two beneficial products, i.e. biogas and digestate. The remaining digestate contains high levels of macro and micro-nutrients and as such presents an environmentally sound alternative to mineral fertilisers. Digestate contains nutrients, which is in the form easily available to plants, with high nitrogen and phosphorus level, as well as from the agronomic point of view can easily diffuse, as it is similar to liquid stable manure [2], [3], [4].

However microorganisms, which are present in digestate, can cause microbial contamination of surface and water body contamination with different sources of digestate from biogas plants [5]. Clostridium spores can contaminate soils and crops when digestate is used as fertilizer, causing a conflictual cohabitation of biogas with traditional cheese productions [6]. Therefore the environmental benefits and risks of digestate still need to be defined. In order to fight bacterial infections and viruses high temperatures, disinfencants and ultraviolet light use usually used. Laser can be used as the source of ultraviolet light. Laser quality to annihilate microorganisms is widely used in clinical practice [7], [8]. During the past two decades laser radiation has been widely used as a principally new tool for studying biological structures and processes and as a factor for influencing them. The interaction of laser light with microorgnisms is a field, which has not been sufficiently well studied. As microorganisms play an important part in modern biotechnology, the investigations in this field are of a significant scientific and practical value.

The aim of this research is to define the influence of laser on total amount of microorganisms in digestate.

\section{MATERIALS AND METHODS}

\section{A. Microbiological investigation}

At the biogas plant which uses cattle manure, maize, food leftovers, animal bedding, biological litter connected with cattle breeding etc. as substrate for biogas production, total 40 digestate samples have been collected and investigated.

Samples were collected in sterile sample bags, using personal protection equipment immediately after the end of fermentation, before putting in storage reservoir. Each sample consists of 5 units (each unit corresponds to $500 \mathrm{ml}$ ). The samples were transported to the laboratory in thermobag, in which the temperature does not exceed $+6{ }^{0} \mathrm{C}$ in order to prevent the reproduction of microorganisms. In the laboratory the total sample was created out of 5 units - using a sterile sample scoop, $100 \mathrm{ml}$ of digestate were taken from each unit and mixed carefully.

For detection and enumeration of bacterial cultures standard Microbiology of food and animal feeding stuffs ISO methods, adapted in Latvia were used, namely: LVS EN ISO 6579:2003/A1:2007 Horizontal method for the detection of Salmonella spp. - Amendment 1: Annex D: Detection of Salmonella spp. in animal faeces and in environmental samples from the primary production stage; LVS EN ISO 6888-1 +A1:2007Horizontal 
method for the enumeration of coagulates-positive staphylococci (Staphylococcus aureus and other species) - Part 1: Technique using Baird-Parker agar medium; LVS ISO 16649-2:2007 Horizontal method for the enumeration of $<$ beta $>$-glucuronidase-positive Escherichia coli - Part 2: Colony-count technique at $44{ }^{\circ} \mathrm{C}$ using 5-bromo-4- chloro-3-indolyl -<beta >-Dglucoronide. Enterococcus spp. ГОСТ 28566-90. Food products. Method for detection and determination of count Enterococci.

Before and after the processing with laser, the total amount of microorganisms in digestate samples was defined (colony forming units CFU/ $\mathrm{ml}$ ). The method is based on LVS EN ISO 4833 - 1:2014 standard Microbiology of the food chain - Horizontal method for the enumeration of microorganisms - Part 1: Colony count at 30 degrees $\mathrm{C}$ by the pour plate technique (ISO 4833-1:2013).

\section{B. Laser processing}

$15 \mathrm{~g}$ of digestate were poured in sterile, $75 \mathrm{~mm}$ in diameter Petri dish. Each sample was exposed to laser processing with invariable wavelength of $\lambda 445 \mathrm{~nm}$ and variable power of 2 and $4 \mathrm{~W}$, scanning speed 20, 40, 60 and $80 \mathrm{~mm} / \mathrm{s}$ (Fig. 1.). Laser systems parameters are given in Table I.

Table I

Laser systems embalaser A3 parameters

\begin{tabular}{|l|l|}
\hline Laser type & Laser diode \\
\hline Wavelength $\lambda[\mathrm{nm}]$ & 445 \\
\hline Laser power P $[\mathrm{W}]$ & $0-4$ \\
\hline Cutting area $[\mathrm{mm}]$ & $297 \times$ x 420 \\
\hline Scanning speed $[\mathrm{mm} / \mathrm{s}]$ & $1-150$ \\
\hline Cooling type & No \\
\hline Assisted gas & Air \\
\hline Focal lens diameter $[\mathrm{mm}]$ & 9 \\
\hline Focus distance $[\mathrm{mm}]$ & $45 \mathrm{~mm}$ \\
\hline Focal spot diameter $[\mu \mathrm{m}]$ & $\sim 200$ \\
\hline \multicolumn{2}{|c|}{ Extra: https://www.laserglow.com/D4F } \\
\hline
\end{tabular}

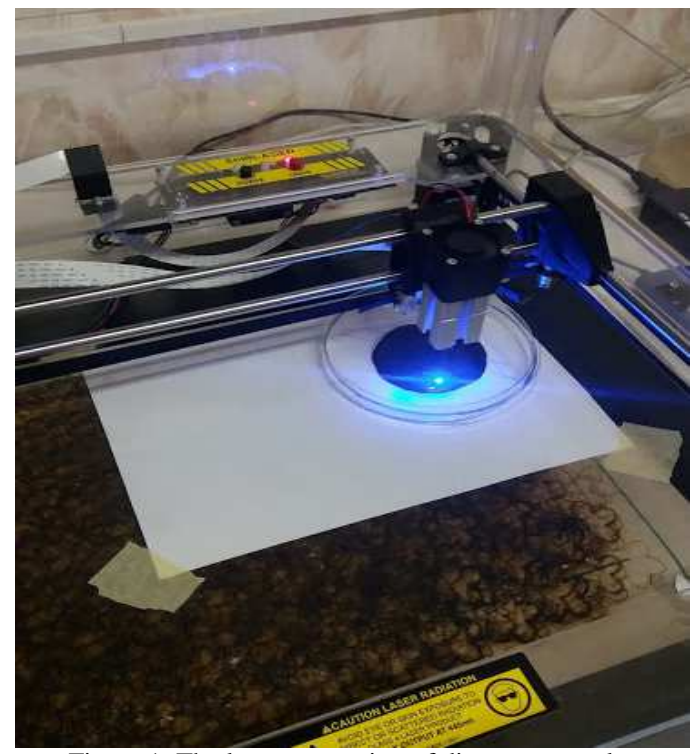

Figure 1. The laser processing of digestate samples
Samples were processed using the method of raster processing (a principle of sequential line scanning) (Fig. 2) with an option for variable interval $d y=100 \mu \mathrm{m}$. In given diameter $(300 \mu \mathrm{m})$ of work spot, every line would overlap about $70 \%$. Each sample was processed 3 times every time rotating the sample by $45^{0}$.

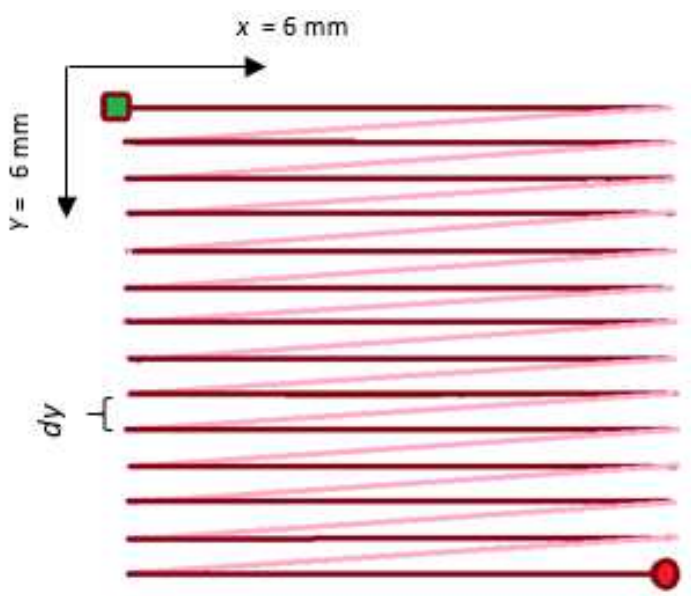

Figure 2. The principle of sequential line scanning

C. Theoretical aspects of the research

The studies were conducted with a diode laser with electromagnetic radiation in the visible part of the electromagnetic spectrum with wavelength $\lambda=$ 445 nm (see Fig. 3).

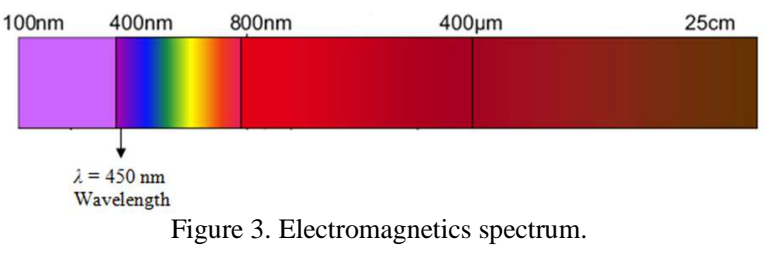

Using the dependence (1) we can calculate the frequency of this electromagnetic radiation

$$
v=c / \lambda=6.74 \times 10^{14} \mathrm{~Hz}
$$

where $c$ is the speed of light in vacuum $-3 \times 10^{8} \mathrm{~m} / \mathrm{s}$.

The energy of an electromagnetic radiation quantum fall on the specimen with colonies of bacteria is determined by the dependence

$$
\begin{gathered}
E=h v=6.74 \times 10^{14} \times 6.626 \times 10^{-34} \\
=1.017 \times 10^{-2} \mathrm{~J}
\end{gathered}
$$

where $h$ is the Planck's constant, $h=6.626 \times 10^{-34} \mathrm{~J} . \mathrm{s}$

The minimum diameter of the focal spot $d_{0}$ is defined by the expression (equation)

$$
d_{0}=M^{2} \frac{4 \lambda}{\pi} \frac{f}{D}
$$


where $f$ is the focus distance, $f=45 \mathrm{~mm}$.

For diode lasers a parametet M2 of quantifiy the beam quality is between $10 \div 20$.

In our experiment the diameter is about $300 \mu \mathrm{m}$.

The power density $q$ which is obtained in the area of the working spot on the sample is

$$
q=P / S
$$

where $S$ is the area of the working spot, $P=4 \mathrm{~W}$,

$$
\begin{gathered}
\mathrm{S}=\pi \mathrm{r}^{2} \\
\mathrm{~d}=300 \mu \mathrm{m} ; \mathrm{r}=150 \mu \mathrm{m} \\
\mathrm{S}=3.14 \times\left(150 \times 10^{-6}\right)^{2}=7.07 \times 10^{-8} \mathrm{~m}^{2} \\
q=4 / 7.07 \times 10^{-8}=5.7 \times 10^{8} \mathrm{~W} / \mathrm{m}^{2}
\end{gathered}
$$

At the fixed constant speed $\mathrm{v}-80 \times 10^{-3} \mathrm{~m} / \mathrm{s}$, the impact time of our experiment is set with the expression

$$
\mathrm{t}=\mathrm{d} / \mathrm{v} \text { - duration of exposure }
$$

where $\mathrm{v}$ - speed of processing; $\mathrm{d}$ - diameter of the focal spot.

$\mathrm{d}=300 \mu \mathrm{m}=300 \times 10^{-6} \mathrm{~m}$

$\mathrm{v}=80 \times 10^{-3} \mathrm{~m} / \mathrm{s}$

$$
\begin{aligned}
& \mathrm{t}=300 \times 10^{-6} / 80 \times 10^{-3}=3.8 \times 10^{-3} \mathrm{~s}=3.8 \mathrm{~ms} \\
& \mathrm{v}=20 \times 10^{-3} \mathrm{~m} / \mathrm{s} \\
& \quad \mathrm{t}=300 \times 10^{-6} / 20 \times 10^{-3}=15.0 \times 10^{-3} \mathrm{~s}=15.0 \mathrm{~ms}
\end{aligned}
$$

The linear density of energy (LDE) during the process of interaction of laser radiation with the target is defined:

$$
\begin{aligned}
\mathrm{LDE}=\mathrm{P} / \mathrm{v} & =4 / 80 \times 10^{-3} \mathrm{~m} / \mathrm{s}=50 \mathrm{~J} / \mathrm{m} \\
& =0.05 \mathrm{~J} / \mathrm{mm} \\
\mathrm{LDE}=\mathrm{P} / \mathrm{v}= & 4 / 20 \times 10^{-3} \mathrm{~m} / \mathrm{s}=200 \mathrm{~J} / \mathrm{m} \\
& =0.2 \mathrm{~J} / \mathrm{mm}
\end{aligned}
$$

The interaction of laser radiation with the substance depends on three groups of factors associated with the laser source (power, wavelength, ect.), the optical and thermal properties of the target and the process parameters (speed, focus distance, step between lines, etc.).

\section{RESULTS AND DISCUSSION}

The microbiological standards for fermentation remains are defined by Eiropean Union regulation R142/2011 addition 5, section 3, paragraph 3 (EU regulation R142/2011), which controls the digestate microbiological pollution. Digestate representative samples, which were taken immediately after the transformation, have to correspond the following standards:

1. Escherichia coli amount does not exceed 5000 $\mathrm{CFU} / \mathrm{ml}$ (one sample consists of 5 units, each of them is investigated as a separate sample);

2. Enterococus spp. amount does not exceed $5000 \mathrm{CFU} / \mathrm{ml}$ (one sample consists of 5 units, each of them is investigated as a separate sample);

3. Salmonella spp. $25 \mathrm{~g}$ has not been stated (one sample consists of 5 units, each of them is investigated as a separate sample);

Fermentation remains, which do not correspond particular requirements, are transformed once again, if Salmonella has been stated, they are liquidated according to the regulations of competent authority.

Digestate is not investigated to the presence of other pathogens, however, their presence is very probable.

In the following research Salmonella spp. has not been stated in any of the samples, E. coli and Enterococcus spp. amount does not correspond EU regulation R142/2011 requirements in any of the investigated samples; Staphylococcus aureus has been stated in 24 samples out of 40 , EU regulation R142/2011 does not regulate the norm of the following microorganisms in digestate, however, $S$. aureus can cause threats to environment (See Table II).

Table II

Microbiological tests results for digestate samples

\begin{tabular}{|l|c|c|}
\hline \multicolumn{1}{|c|}{ Parameter } & $\begin{array}{c}\text { Average } \\
\text { CFU/ ml }\end{array}$ & SD \\
\hline Salmonella spp. & 25 g not stated & - \\
\hline Enterococcus spp. & 20470 & \pm 4114 \\
\hline Escherichia coli & 14640000 & \pm 1680000 \\
\hline Staphyloccus aureus & 165 & \pm 35 \\
\hline
\end{tabular}

Total number of bacterial colony in non-processed digestate at the dilution $1 * 10^{-14}$ and $1 * 10^{-15}$ has been shown in Table III.

Table III

The total number of microorganisms for digestate samples

\begin{tabular}{|c|c|c|}
\hline $\begin{array}{c}\text { Non-processed } \\
\text { digestate dilution part }\end{array}$ & $\begin{array}{c}\text { Colony forming } \\
\text { units } \\
\text { CFU/ ml }\end{array}$ & SD \\
\hline $1 * 10^{-14}$ & 192 & \pm 41 \\
\hline $1 * 10^{-15}$ & 82 & \pm 29 \\
\hline
\end{tabular}

The impact of laser on total number of digestate at the dilution $1 * 10^{-14}$ and $1 * 10^{-15}$ is shown in Figures 3, 4. In given scanning speed interval experimental data can be approximated using following equation

$$
N=A \cdot v^{B},
$$

where $\mathrm{N}$ - number of microorganism colonies; $\mathrm{A}=$ const $\mathrm{B}=$ const. 
With the laser scanning speed $20 \mathrm{~mm} / \mathrm{s}$ and power $4 \mathrm{~W}$, the total number of microorganism colonies in digestate at the dilution $1 * 10^{-15}$ has decreased to 93 $\%$, at dilution $1 * 10^{-14}-90 \%$. By decreasing laser speed and increasing power, the total number of microorganism colonies has decreased.

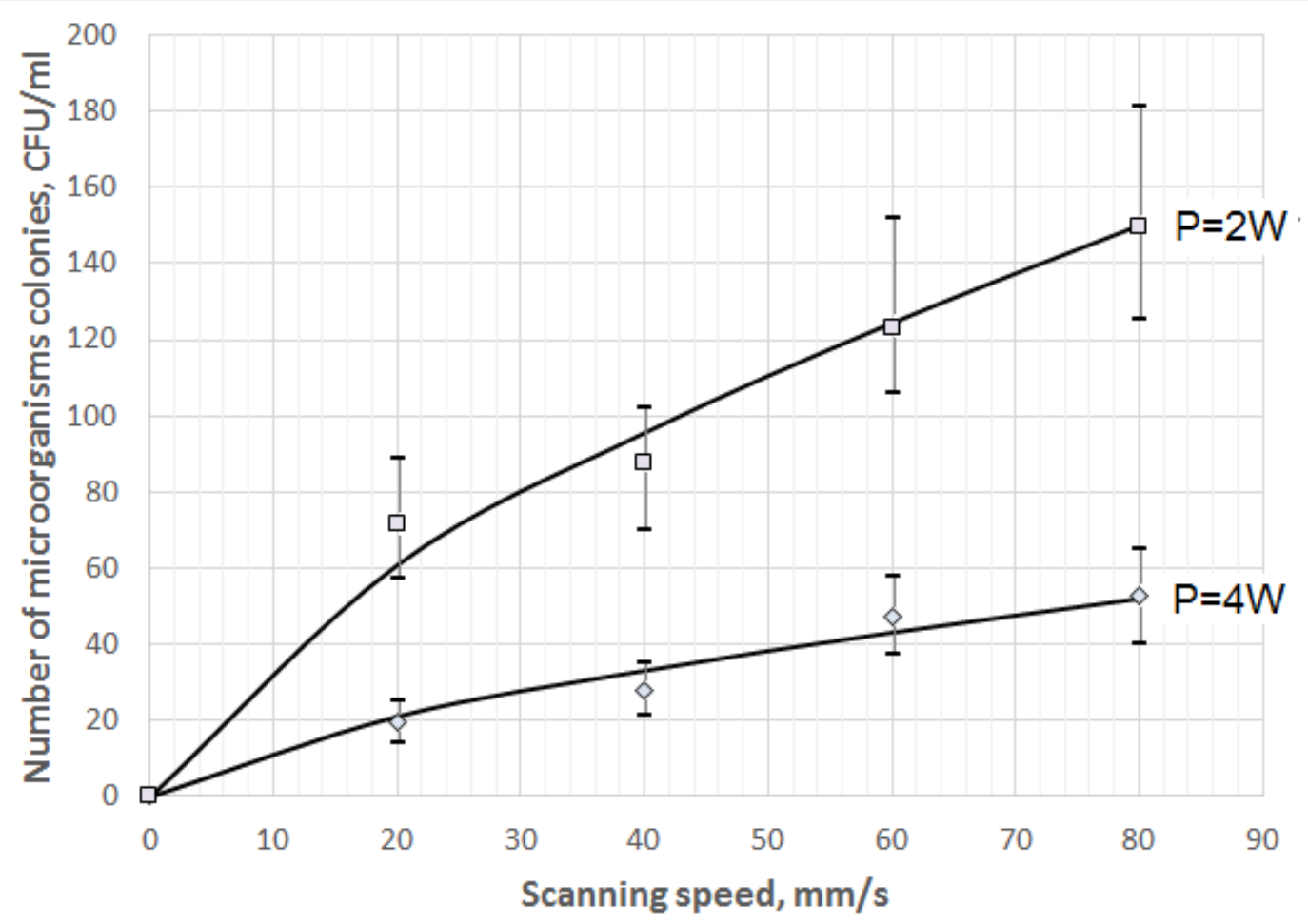

Figure 3. The total number of microorganism colonies (CFU/ml) after digestate processing with variable laser power and scanning speed (digestate dilution part $1 * 10-14$ ). If $\mathrm{P}=4 \mathrm{~W}$, then $\mathrm{A}=3.0, \mathrm{~B}=0.65$; if $\mathrm{P}=2 \mathrm{~W}$, then $\mathrm{A}=8.7, \mathrm{~B}=0.65$

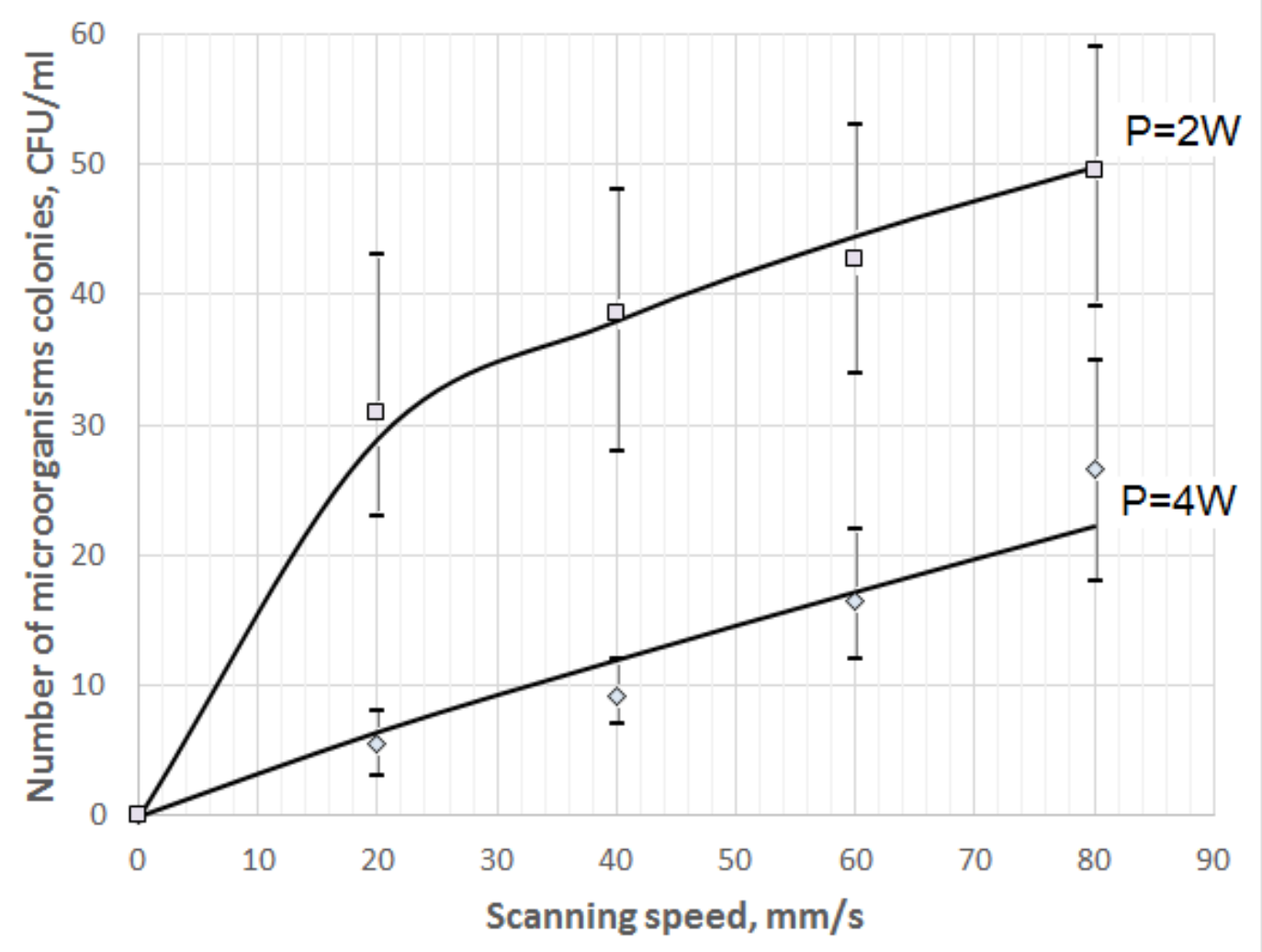

Figure 4 . The total number of microorganism colonies $(\mathrm{CFU} / \mathrm{ml})$ after digestate processing with variable laser power and scanning speed (digestate dilution part $1 * 10^{-15}$ ). If $\mathrm{P}=4 \mathrm{~W}$, then $\mathrm{A}=0.45, \mathrm{~B}=0.89$; if $\mathrm{P}=2 \mathrm{~W}$, then $\mathrm{A}=9.0, \mathrm{~B}=0.39$ 
The bactericide impact of UV rays is based on photochemical reactions which result in irreversible damage of DNA. UV rays have an impact not only on DNA but also other cell structures, partly on RNA, cell membranes etcetera [9]. The strongest bactericidal qualities has the UV light with wavelength 250-265 $\mathrm{nm}$ [10] and 200-295 nm [9]. Laser with wavelenght $266 \mathrm{~nm}$, impulse time $30 \mathrm{ps}$ and frequency of $100 \mathrm{MHz}$ provides power of about $300 \mathrm{~kW}$. According to calculations, this much power is enough to destroy $90 \%$ of bacterial cells on in area of 1 ha, both on soil surface and lowest parts of atmosphere [11]. The UV sensitivity of different viruses and bacterial cells heavily differs [9]. The low-level laser radiation has an antibacterial effect on Staphylococcus aureus, Escherichia coli, Klebsiella pneumoniae, Pseudomonas aeruginosa (microorganisms - surgically infectious agents). The most expressed bactericidal effect was registered in laser radiation of the green spectral range $(\lambda=527 \mathrm{~nm})$ [12]. E. coli bacteria inactivation by high-power laser irradiation is solely based on a thermal process [13].

\section{CONCLUSIONS}

By decreasing laser scanning speed and increasing power, the total number of microorganism colonies has decreased. With the diode laser with electromagnetic radiation in the visible part of the electromagnetic spectrum and wavelength $\lambda=445$ $\mathrm{nm}$, laser speed $20 \mathrm{~mm} / \mathrm{s}$ and power $4 \mathrm{~W}$ the total number of microorganism colonies in digestate decreased $90-93 \%$.

Further research intends to process the digestate with different types of lasers and different wavelengths. The impact of laser on microorganisms depending on the thickness of digestate layer and various types of microorganisms is to be researched as well.

\section{REFERENCES}

[1] Goberna M., Podmirseg S.M., Waldhuber S., Knapp B.A., García C., Insam H., "Pathogenic bacteria and mineral $\mathrm{N}$ in soils following the land spreading of biogas digestates and fresh manure," Applied Soil Ecology, vol. 49, pp. 18-25, 2011.
[2] Bioenergy, Association of New Zeland Inc. The production and use of digestate as fertiliser. Banz Technicalguide. 2013.

[3] Svensson K., Odlare M., Pell M. "The fertilizing effect of compost and biogas residues from source separated household waste," Agric. Sci., vol. 142, pp. 461-467, 2004.

[4] Gómez-Brandón M., Fernández-Delgado Juárez M., Zangerle M., Insam H. "Effects of digestate on soil chemical and microbiological properties: A comparative study with compost and vermicompost," Journal of Hazardous Materials, vol. 302, pp. 267-274, 2016

[5] Studer I., Boeker C., Geist J. "Physicochemical and microbiological indicators," Ecological Indicators, vol. 77, pp. 314-322, 2017.

[6] Pulvirenti A., Ronga D., Zaghi M., Rita A., Mannella T., Pecchioni N. "Pelleting is a successful method to eliminate the presence of Clostridium spp. from the digestate of biogas plants", Biomass and Bioenergy," vol. 81, pp. 479-482, 2015.

[7] Migliorati E. K. J. Lasers and bacterial reduction: A comprehensive technique to treat chronic periodontitis. [Online]. Available: http://www.dentistryiq.com/articles/ wdj/print/volume-2/issue-2/focus-on-perio/lasers-andbacterial-reduction-a-comprehensive-technique-to-treatchronic-periodontitis.html [Accessed: 01.02.2017.].

[8] Stepp H., Andersson-Engels S. "Editorial Therapeutic laser application and tissue interactions: Bringing light into clinical practice," Biophoton, vol. 3 (5-6), pp. 259-260, 2010.

[9] Lavrentjeva L.V., Avdeev S. M., Sosnin E. A., Velicevskaja K. J. "Analysis of excilamps UV radiation bactericide action on pure microorganism cultures," Tomsk State University Journal of Biology, vol. 2(3), pp. 18-27, 2008. Лаврентьева Л.В., Авдеев С.М., Соснин Э.А., Величевская К.Ю. 2008. Бактерицидное действие ультрафиолетового излучения эксимерных и эксплексных ламп на чистые культуры микроорганизмов. Вестник Томского государственного университета. Биология. 2(3): 18-27.

[10]Eglīte M., Aulika B., Avota M. Environmental health. 2008. Rīga Stradinš̌ University. Vides veselība. Rīgas Stradina universitāte. 2008. 696 lpp.

[11]Medvedev M., Gorbovskij S. "Destroying of pathogenic mycrobes using laser berams", Bulletin about atomic energy, vol. 8, pp. 43-45, 2003. Медведев М., Горбовский С. 2003. Уничтожение патогенных микробов с помощью лазерного излучения. Бюллетень по атомной энергии, 8: 43-45.

[12] Kasumyan A.S., Azoskova O.V. "Antibacterial effects of lowlevel laser radiationwith different wave length," Smolensk State Medical almanac, vol. 1 (1), pp. 31-33, 2015. Касумьян А.С., Азовскова О.В., Лелянов А.Д., Федосов Е.А. 2015. Антибактериальное действие низкоинтенсивного лазерного излучения с различной длиной волны. Смоленский медицинский альманах 1 ( 1 ): 31-33.

[13]Hibst R., Graser R., Udart M., Stock K. "Mechanism of highpower NIR laser bacteria inactivation," Journal of Biophotonics, vol. 3 (5-6), pp. 296-303, 2010. 